\title{
THE SEXCENTENARY OF THE MARTYRDOM OF RAYMOND LULL
}

ON the 30th of June 1315 Raymond Lull was stoned to death at Bugia in North Africa by a Mohammedan crowd, enraged because the aged philosopher-missionary persisted in his attempts to preach the gospel of Christ to the Moslems of North Africa.

Raymond Lull united, though he scarcely harmonized, the most diverse gifts and activities. As a fertile and popular poet he was a master of the tongue and letters of Spain, and his writings are an important element in the growth of the earlier Spanish literature. He was a fiction writer, and his tale entitled Blanquerna has been characterized as the medieval Pilgrim's Progress; his songs, too, live in the mouths and memory of the people. He was a philosopher of mark, though he did not take a foremost place among the schoolmen. He was an honoured teacher and had a large following of enthusiastic disciples whose devotion procured him the title of 'doctor illuminatus.' He was an Orientalist, too, and his knowledge of Arabic was almost without parallel among western scholars in the Middle Ages. But that which marks him as unique in the history of his age is the call which he felt to carry to the Mohammedan world the gospel of the love of Christ, and the singleness of purpose with which he followed it till he met a martyr's death.

When Raymond Lull was born in 1235, six centuries had elapsed since the death of Mohammed and the emergence of his religion from Arabia to overspread the southern Mediterranean basin and many other lands. Before Lull's death in 1315 the only organized resistance of Christendom to Islam, the Crusades, had come to an impotent conclusion, 
and the Arab power of the Saracens had triumphed against the Frank and the Saxon. Since the death of Lull six more centuries have passed during which another race, the Turkish, assumed the leadership of Islam, till it now stands at the crisis of its fate. Meanwhile the political aspect of Islam has been profoundly changed, and it bids fair to change still more. The passing of two-thirds of the Moslem world under the rule of Christian powers has been accompanied by an entirely new phase of its religious development. It has come into contact with new aspects of Christianity; first, the intellectual and social culture which has developed in Europe during the last four and a half centuries, and next the spiritual movement which is embodied in modern missions, both of which have affected Islam either by way of influence or reaction. And it is surely a suggestive coincidence that the sixth centenary of Lull's death should synchronize with a world struggle of vaster dimensions than the Crusades. But this struggle is no war of religions: Mohammedans as well as Christians are fighting on both sides in accordance with their temporal interests, a fact which is bound yet further to modify both political and religious relations between Christendom and Islam. We may well take occasion to carry back our thoughts over six centuries and ask what it was, amid the chimeras of scholastic philosophy, which made Raymond Lull such a living force that he speaks to us in clear tones through the ages, and that his message is well worth pondering and acting on to-day.

The most astonishing aspect of the relation which obtained between the two faiths in the Middle Ages is the abysmal ignorance of Islam which prevailed in Western Christendom, notwithstanding the long intercourse of the Crusades. Though the religion of Mohammed was by far the greatest opponent with which the Church had to deal, yet the decrees of the later councils scarcely mention it, much less define an attitude towards its tenets. The very name of Islam was practically unknown; Christians only 
thought of Saracens, a name probably derived from an obscure district in Arabia. Alanus ab Insulis (died 1208) writes a treatise against 'Pagans or Mohammedans.' 'Mahomet' was corrupted into 'Baphomet' and believed to be the name of a malignant demon, while 'Mahoun' occurs in the same way in Chaucer and Shakespeare. In the Near East the Khalifas had made liberal use of Christian officials and scholars, and it was to the latter that medieval Moslem scholars owed their introduction, by means of Arabic translations, to the philosophy of the Greeks which they afterwards developed in their schools. But in this intercourse the rulers favoured heretical Christians rather than the orthodox, these being connected with the Emperors of Byzantium; hence it was the Nestorian church which was able to carry on extensive missionary operations far eastwards up to the thirteenth century. Among orthodox teachers John of Damascus (died 760), himself for long an official under the Saracen rulers of Palestine, first grasped and presented Islam as a whole and provided a Christian refutation of it in his Fountain of Knowledge, and this exposition remained the basis of anti-Moslem polemic for centuries, till at length the wide-hearted Petrus Venerabilis (died 1156) gave to Europe the first translation of the Koran, of course in Latin. His object was to show the real nature of the Moslem faith and to stimulate theologians to confute it, and he hoped that the Bible might also be translated into Arabic. His standpoint is a great advance on that of previous writers; for while he regards Islam as the most weighty and systematic of attacks on Christianity, he distinguishes in it Christian, heretical, Jewish and pagan elements, and demands that the true should be recognized and the false repudiated.

As regards evangelization, the Western Church during the Middle Ages was preoccupied with gathering the northern nations into her fold, but this would hardly have prevented her from dealing with Islam had it not been for the attitude which the two faiths from the first assumed to each other, 
not as religions but as states. It was the Holy Roman Empire against the infidel Eastern power of the Saracens. Attacked from the first by Islam with the sword 'in the way of Allah' Christian nations fought for their existence and kept it or lost it, together with their faith, according to the result of battle ; and thus for centuries Christendom had little idea of combating Islam save with the sword. Petrus Venerabilis is the first doctor of the Church who takes a non-militant attitude. True he is undecided whether to call Mohammedans heretics or heathens, though, on the whole, he thinks they cannot be considered heretics, for they never elected to leave the Church; in fact they have never really known true Christianity. While, however. he urges Christians to oppose Islam he prefaces his apology of the Christian faith with the golden words addressed to Moslems : 'I approach you, not as our people often do, with weapons but with words, not with force but with argument, not with hatred but with love.' This acknowledgement that the repulsions of Islam owe their force to the corruptions of Christianity, and the conviction that the only power which will overcome that repulsion is the force of Christian love, are still the basal principles of sound work among Moslems to-day. But if Petrus Venerabilis laid them down, it was Raymond Lull who first translated them systematically into action.

Raymond Lull was born at Palma on the island of Majorca. He belonged to a distinguished Catalonian family and his youth and early manhood were spent in a luxurious home and amid the pleasures of dissolute court life, which coloured his literary pursuits. The turning-point of his career in 1266 was a vision of Christ which arrested and changed him in the full tide of licentious pleasure. He withdrew, after the manner of the age, not only from dissipation but also from domestic life and became a "tertiary' (lay brother remaining in secular life) of the Franciscan order, but never a priest. Not, however, for contemplative inactivity had he thus withdrawn; the burden 
of'his prayers was: 'Lord, what wilt thou have me to do?' He not only saw the rising tide of Saracen conquest and heard the voice of Petrus Venerabilis; he also meditated on the example of Francis of Assisi who in 1219 had visited the Sultan of Egypt and preached to him of Christ, being honourably treated, but carefully excluded thenceforth. Lull felt that the call had come to him to approach the Saracen with the gospel of Christ's love, but how could he do this effectively himself and secure a continuance of such influence? With an insight remarkable in a medieval scholar whose whole intellectual world was dominated by the Latin tongue, he realized that in order to reach the Saracens he must master and use their language. To give continuity to the work schools must be established for the study of Arabic and other eastern languages. To gain an influence over the scholastic world the missionary must teach after the manner of the age in its universities, and seek out the princes of the Church and of the world to persuade them to forward his projects. And chiefly, the scholar must himself go, at the risk of life itself, to preach to the fanatical Moslem in the spirit of humility and love. But first he must give himself to preparation by prayer and study, and this he did for nine years.

The effort to carry out these aims is the story of Raymond Lull's life. In order to learn Arabic he acquired a Saracen slave whom he used as his tutor for some years till the slave, discovering the purpose of his employment, blasphemed Christ. His master in wrath struck him, whereupon the Moslem wounded Lull with his weapon and presently committed suicide in prison. Lull was not the only missionary to Moslems who has had to suffer from the temper of his teacher, or to regret his own imperfect self-control under provocation. In 1276 a school was established by Lull at Miramar in Majorca, for the study of Arabic, with which was joined, by a true insight, that of geography. Later on we have a letter to the university of Paris in which Lull appeals for the founda- 
tion of chairs not only of Arabic and Greek, but also of the Tatar language, and expresses the apprehension-so fully justified by history - that the Tatars, if not then approached with the Gospel, might become either Jews or Mohammedans. In the Russian Empire the Tatars now form the leading Mohammedan community. In 1807 he appeals to the Holy See for the establishment of four or five monasteries for the study of missionary languages, but he adds a petition for the amalgamation of the various orders of knights into one which should wage systematic warfare against the Saracens, first in Granada, then in North Africa, and finally in Syria. Thrice at Rome and once at Avignon Lull sought, with little success, to gain the support of the head of Western Christendom for his plans. The ideas of the Popes of his time, if directed at all to the repulse of Islam, could get no further than a fresh crusade. But the Council of Vienne in 1811 gave him a better opportunity, and in 1812 it issued a decree for the establishment of schools for Hebrew, Greek, Arabic, and Chaldee in Rome, Oxford, Bologna, Salamanca, and Paris. The practical effect of this decree apparently was not great, though it would seem that the teaching of Hebrew at Oxford dates from this time.

Lull's activity as a teacher and as a writer was extraordinary. After his nine years of preparation and the foundation of the missionary college at Miramar, he repaired first to Montpelier and then to Paris as a teacher of scholastic philosophy, and he was a most prolific writer on its doctrines. His works of this kind (besides his poems and stories) number over two hundred, but even the chief of them, his Ars Magna, is a futile attempt to solve the mysteries of knowledge by means of mathematical diagrams. Its chief point of interest is Lull's polemic against the teachings of the school of the great Moslem philosopher Ibn Roshd, known to Westerns as Averroes (1126-1198). Through Christian translators Greek philosophy had reached the Arabs of Baghdad and afterwards those of 
Spain, and among them it was Averroes especially who reintroduced Aristotle, albeit in a modified form, to Europe. He taught that matter is eternal and that God is the transcendent Thought which is the cause of movement in the universe, but not being in direct contact with the world is therefore uninfluenced by prayer; while man, as such, has no immortality. His followers went further, and when pressed to reconcile their teaching with the doctrines of religion, laid down the thesis that things might be true in faith which were false in philosophy. This doctrine aroused the strongest opposition on the part of Lull. He could not allow that philosophy and faith might possibly be inconsistent, and though his outlook was limited, and his method of argument faulty, yet his principle that the certainties of faith must ultimately be in harmony with true knowledge was both sound and fruitful. Still more so was his eager determination to carry into practice the knowledge which he had attained and the doctrine that he taught. This was shown most of all in his missionary journeys.

The first of these was in 1291, four years after he had begun to lecture as an acknowledged professor in Paris. His enterprise was greeted with great enthusiasm at Genoa where he went to embark for Tunis, but his courage failed him at the prospect of disgrace, danger, and possible death. The vessel in which his passage had been taken sailed without him, and Lull sank into despair, believing that, though his message was true, he himself was reprobate. His mental distress brought on fever which did not yield till his friends consented to put him on board a vessel bound for Tunis. He was received as a wandering philosopher and given the opportunity of publicly disputing with the Moslem divines of Tunis. He took as his point of departure the attributes of God (a subject much laboured by Moslem doctors), and used the argument, not unfamiliar to us, that self-communication, as essential to the highest conception of goodness, involves the trinity of 
the divine nature; and that without the trinitarian conception matter must be conceived as eternal, otherwise God would have been inactive before creation. Before long Lull's opponents became alarmed at the effect of his arguments and personality on the hearers; he was denounced to the king, imprisoned and sentenced to death according to Moslem law, but the influence of friends procured a commutation of the sentence to that of perpetual banishment. He slipped away from the vessel which was to take him to Italy, and lay concealed on another in the harbour for a while, in the hope of returning to the shore, meanwhile writing one of his philosophical works, but eventually he had to return to Naples.

In 1300 Lull succeeded in converting many Moslems on his own island of Majorca, the chief definite result of his missionary labours. Thence he went to Cyprus, but apparently received little encouragement from the Christian king, and proceeded to Armenia hoping to promote a mission to the Tatars. In 1306 Lull landed at Bugia, 300 miles westward of Tunis, and began preaching at large in|Arabic. Imprisonment speedily followed, and for six months he remained in confinement, sedulously plied by his Moslem custodians with every inducement to recant. At length the ruler, out of respect for his character and regard for relations with Christian powers, had him deported, with a second stringent prohibition of return. The third and last attempt was made in the eightieth year of his age. Like other great missionaries of ancient and modern times Lull had a longing for the crown of martyrdom. He left Majorca for Bugia in August 1314, and after landing he is said to have occupied himself for some months in secretly visiting and strengthening those who had been converted during his former visits. But such work could not long satisfy his fiery spirit. He came forth into the public square, boldly preaching Christ and controverting Islam, and presenting himself to the people as the man who had already been banished for this very cause. The fury of 
the populace broke loose, and at the king's command, or with his consent, they dragged Lull to the seashore and stoned him to death on June 30, 1315. His body rests in the church of St. Francis at Palma on Majorca.

The significance of the work and life of Raymond Lull for our age comes out most clearly if we relate it to three main aspects of Islam as a religion : its rationalism, its mysticism and its legalism. ' It is a boast of many Moslems of the modern school that their faith of all world religions makes the least demand upon a belief in the supernatural, since it possesses a founder who laid no claim to miraculous powers and who repudiated the mysteries of the Trinity and the Atonement. There is a class of minds to whom this position makes an appeal. But on the other hand, there are very many, especially in India and Persia, to whom a religion without mystical union and communion between the divine and the human is quite unsatisfying, and it was the great achievement of the Moslem divine Ghazzali (1059-1111) that after his conversion from scepticism to a belief in divine revelation he succeeded in gaining for mysticism an acknowledged place in the teaching of Islam. Lull stood for the direct contact of the soul with God as the basis of all piety, whether in devotion or action, while at the same time he strenuously vindicated the imperious necessity of the apprehension and presentation of the faith through the intellect. The right balance of these two sides of the Christian message to Islam is the touchstone of missionary method in this direction. Some missionaries and the majority of zealous converts have been inclined to lay the greater stress on a logically convincing presentation of doctrine, and their witness has mostly failed to reach the Moslem seekers after God who are conscious of real communion with $\mathrm{Him}$ in the secret of their souls. But there are a few missionaries and some scholars who lay so much emphasis on the mystical side of Moslem religious life as the great avenue of approach for the Christian missionary, that 
they would have us go very far in pressing the identity of such experiences in all religions, regardless of differences of doctrine. We have to combine the way of the mystic with the truth of the religious teacher. The Christian life is at once a possession and a quest.

Over against the legalism of Islam, Lull stood for the power of Christian love. Despite the aberration of once advocating temporal war against the infidel the whole tenor of his life and death is embodied in such words as these : 'It is my belief, $O$ Christ, that the conquest of the Holy Land should be attempted in no other way than as Thou and Thine apostles undertook to accomplish it-by love, by prayer, by tears, and the offering up of our own lives.' And again : 'He who loves not lives not. He who lives by the Life cannot die.' This love is the force which penetrates to the heart of the Moslem, and the missionaries who have most effectually drawn him to Christ have been those in whom it was most strikingly manifested. It is represented by the work of the medical missionary which has softened and changed the most fanatical hearts so that the death of a Pennell is mourned by a whole countryside of fierce marauders. It is the same impulse which breaks out in the desire for martyrdom, as when Raymond Lull writes: 'Although, 0 God, I am unworthy of dying for Thee, nevertheless $I$ do not give up the hope of obtaining this holy and precious death'; or when Henry Martyn expresses his desire to burn out for Christ, and instead of going home for medical treatment and nursing takes the toilsome journey to Shiraz in burning summer heats that he may not fail of giving the New Testament in their own tongue to the Shias of Persia ; or when Thomas Valpy French, even after his elevation to the episcopate is never so happy as when he returns from preaching to Mohammedans covered with the marks of stones and spitting, and at last resigns his bishopric for a lonely life of privation and toil at Muscat till his body succumbs to the flerce heat of the climate without and of 
fever within. The spirit of longing to offer and be offered for Christ which spurns the love of comfort and of life itself is the spirit which speaks in language intelligible to the Moslem.

Alongside of mystical devotion and selfconsuming zeal we see in Lull also an element of practical and farsighted statesmanship. His long personal preparation and his tenacious efforts to found permanent missionary seminaries embody the principle, at long last being acted on systematically by the Church of Christ, that if the Moslem is to be effectually approached, the messenger must be diligently and thoroughly trained. A great world religion with its theology, philosophy and literature cannot be dealt with adequately by amateur work. If we would. meet its needs and correct its errors we must understand its working and its inner meaning. We may be thankful that such organizations as the Study Centre for Arabic and Islam in Cairo and the Board of Study for Preparation of Missionaries at home are working to meet this need, and that the Roman church, too, is initiating systematic training for its missionaries to Moslems.

Even the mistaken desire of Raymond Lull for the use of force may not be without its lesson. For more than eleven centuries the presentation of the Gospel to the Moslem, living everywhere under rulers of his own faith, was, as the history of Lull shows, practically impossible; and it was probably this condition of things which clouded his otherwise clear insight and threw him back for a moment on the idea of physical conquest. At any rate the pendulum of religious toleration has swung to the opposite extreme, when, under a conscientious but mistaken idea of political wisdom, the progress of Islam among pagans is actually favoured and the access of the Christian messenger to Moslems is barred. On both sides we fall back on the principles enunciated by Sir Herbert Edwardes, one of the saviours of the Panjab in the mutiny, when, being officially commissioner of Peshawar, he was 
advocating as a Christian the establishment of a mission in that turbulent centre of Moslem fanaticism. After insisting, first on the moral obligations of governmental neutrality, and next on the personal obligation of the Christian to evangelize and the protection due equally to him and to his hearers, he concludes with the ever memorable words : 'Above all, we may be quite sure that we are much safer if we do our duty than if we neglect it; and that He who has brought us here with His own right arm will shield and bless us if, in simple reliance upon Him, we try to do His will.'

Raymond Lull has taught us that the true spirit and method of our approach to Islam is to give the Moslem the best we have in the best way we can, with no assumption of superiority or right to censure, but in the attitude of friendly service. And that is only another way of saying that we must do it in the Spirit of Christ.

H. U. WEITBRECHT 